IFAS Extension

\title{
Women and Money: Unique Issues - Money and the Family ${ }^{1}$
}

\author{
Lynda Spence, Martie Gillen, and Diann Douglas ${ }^{2}$
}

Societal dynamics and their effects on gender roles and family structures underscore a distinct need for financial management education to address the unique issues that women may encounter. This series of EDIS publications, "Women and Money: Unique Issues," encompasses financial management for women across the life cycle and through family transitions. This series focuses on the changes women may encounter throughout their lives and the impact of these changes on their economic status. For the rest of the publications in the series, see http://edis.ifas. ufl.edu/topic_series_women_and_money_unique_issues.

\section{Introduction}

Ask any parent and he or she will tell you - it costs money to raise children. Taking into account inflation, a middleincome family may spend more than $\$ 295,000$ to raise a child born in 2011 to the age of 17, according to a USDA report (Lino 2012). This is not a small amount of money, so you will need to know the types of expenses required to raise your family.

This publication reviews the costs associated with raising children and gives you tips on how to teach your children about finances. By knowing the costs of raising your family and setting up a budget, you can teach your children money management skills that will help them throughout their lives.

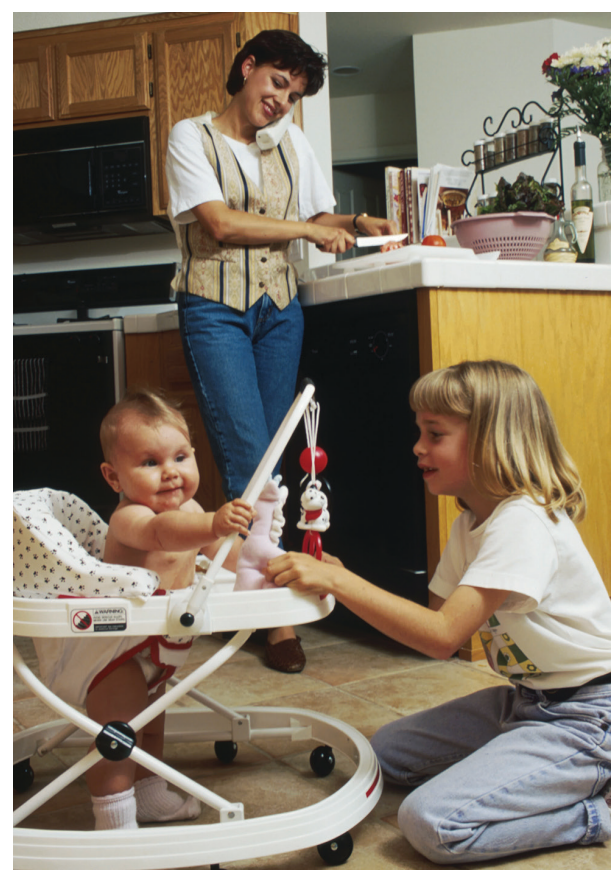

Figure 1. There are many costs associated with raising children; the more you are aware of the expenses, the easier it is for you to plan for them.

Credits: Ingram Publishing

The USDA report includes the following major expenses for raising children - housing, food, transportation, clothing, health care, child care and education, and miscellaneous. If broken down into percentages, the major expenditures show the following averages: $30 \%$ housing, $16 \%$ food, $8 \%$ health care, and $18 \%$ child care and education. These

1. This document is FCS7250, one of a series of the Department of Family, Youth, and Community Sciences, UF/IFAS Extension. Original publication date: March 2013. Please visit the EDIS website at http://edis.ifas.ufl.edu.

2. Lynda Spence, Extension agent I, UF/IFAS Extension Marion County; Martie Gillen, assistant professor and Family and Consumer Economics for Older Adults specialist, Department of Family, Youth and Community Sciences; and Diann Douglas, county Extension director and Extension agent IV, UF/IFAS Extension Madison County; UF/IFAS Extension, Gainesville, FL 32611. 
estimates do not include costs for a college education or education beyond high school, or the costs associated with pregnancy.

\section{Housing}

Housing expenses consist of the following:

- shelter (e.g., mortgage payments, property taxes, or rent; maintenance and repairs; and insurance)

- utilities (e.g., gas, electricity, fuel, phone, and water)

- house furnishings and equipment (e.g., furniture, floor coverings, major appliances, and small appliances)

\section{Food}

Food expenses include food and nonalcoholic beverages purchased at grocery, convenience, and specialty stores; dining at restaurants; and household expenditures on school meals.

\section{Transportation}

Transportation expenses consist of monthly payments on vehicle loans, down payments, gasoline, motor oil, maintenance, repairs, insurance, and public transportation (including airline fares).

\section{Clothing}

Clothing expenses include children's apparel such as diapers, shirts, pants, dresses, suits, shoes, and other footwear. These expenses also include clothing care such as dry cleaning, alterations, and repairs.

\section{Health Care}

Health care expenses include medical and dental services not covered by insurance, prescription drugs and medical supplies not covered by insurance, and health insurance premiums not paid by an employer or other organization. Medical services include those related to physical and mental health.

\section{Child Care and Education}

Child care and education expenses include day care tuition and supplies, babysitting, elementary and high school tuition, and books, fees, and supplies for private or public schools. Other school-related expenses may include backto-school clothes, supplies, publications (e.g., a dictionary), yearbooks, pictures, field trips (sometimes these can cost above \$35), musical instruments, and uniforms.

\section{Miscellaneous}

Miscellaneous expenses include personal care items (e.g., haircuts, toothbrushes, etc.), entertainment (e.g., portable media players, sports equipment, televisions, computers, etc.), and reading materials (e.g., nonschool books, magazines, etc.).

Expenses per child decrease as a family has more children. Families with three or more children spend 22\% less per child than families with two children. For example, with more children, families can have children share bedrooms, hand down clothing and toys to younger children, purchase food in more economical quantities, and even take advantage of sibling discounts at private schools or child care centers.

Table 1 represents overall annual estimated costs of a oneparent household with an annual income less than $\$ 59,410$.

\section{A Team Effort}

Given today's economy, the cost of raising your family can seem overwhelming. Do not be discouraged. Be a team leader and set a goal to have your family gain financial success. Involve your children in the effort, and let them help according to their ages and competencies.

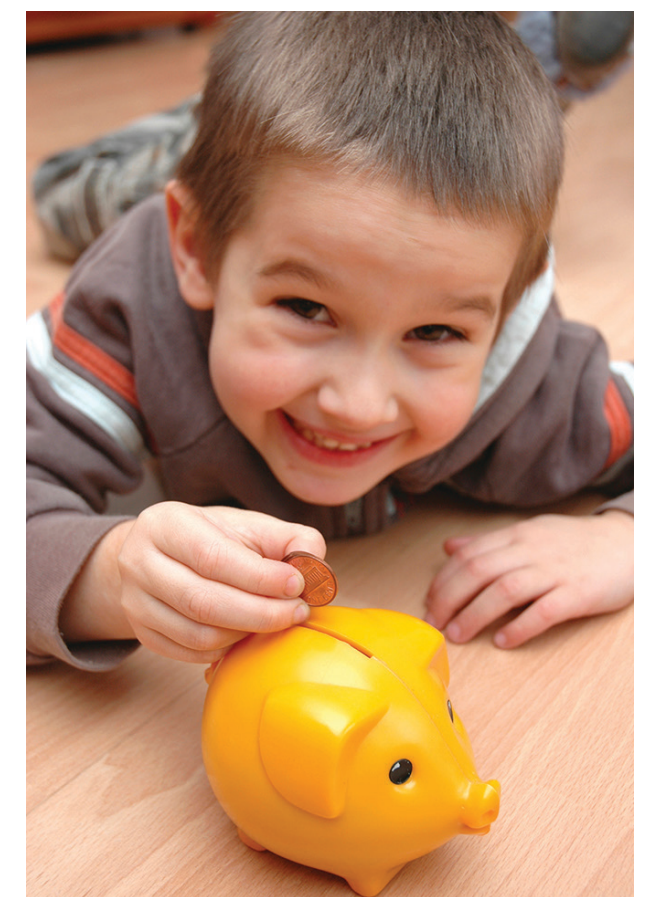

Figure 2. Teaching your children about saving and budgeting can help turn them into adults with good money management skills. Credits: iStockphoto 


\section{Modeling Positive Money Behaviors}

Studies find that children will model behaviors they see acted out in the home. If you manage your finances using a carefully thought-out plan (a budget), consider the valuable lessons you can teach your children about responsibility and independence. Depending on your child's age and ability to understand the concepts, you can give them small lessons about the family finances. For example, you could use the following lesson.

Mini-Money Lesson: You can avoid late-fee penalties by paying bills on time, and you can avoid overdraft fees by only writing checks using money already in your account. These two missteps alone could cost you up to $\$ 100$ in fees. What could the family do with $\$ 100$ if it weren't paid out in fees?

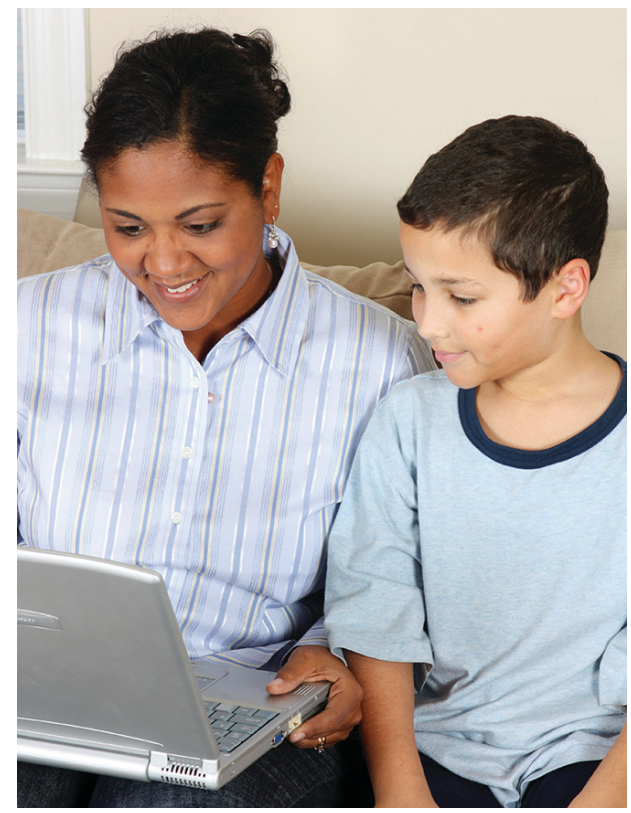

Figure 3. Use small lessons to teach your child how to handle money. Credits: Hemera

\section{Money Management Skills and Children}

Teach your children about earning, saving, responsible spending, and borrowing so that they will have the opportunity to develop money management skills.

\section{Save, Share, Spend}

Talk to your children about a give-and-take approach to money. Ask them:

1. What would you like to save for in the future (a horse, a car, college)?
2. Who do you want to share your money with (a charity, disaster relief)?

3. What would you like to spend your money on (a game, a toy, vacation)?

Talk with your children about putting money aside for each of these three categories. Make suggestions about how it can be done. Will they use coin banks? Will you open a savings account for them? Make sure they are part of the process for safekeeping their money.

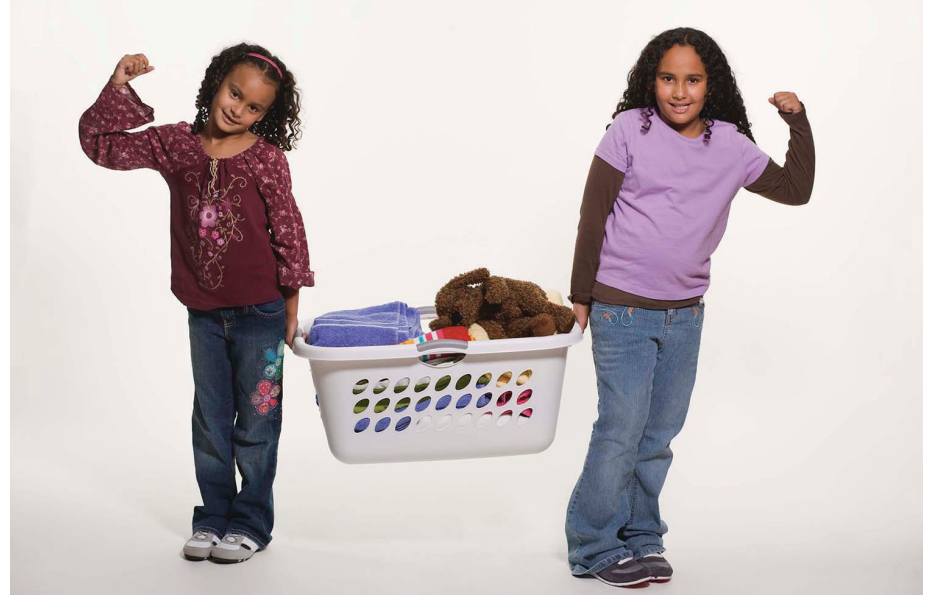

Figure 4. One way to teach your children about money is to pay them for doing chores around the house.

Credits: Jupiterimages

\section{Allowance}

An allowance is one approach to teach children about money management. Use money you have already set aside in your budget to spend on your child. This will keep you from overspending on your child and will help you stick to your budget. Factors to consider when paying your child an allowance include how much money you have to give, what age to start, how often, and how much to offer. The plan will change from time to time according to the child's age and competencies. To avoid confusion, put the plan in writing and make changes when needed. Be open about why you are making changes. Keep it simple, but, by all means, communicate.

\section{Wages or Fee for Tasks}

Paying your child wages for accomplishing tasks and completing chores serves as another teaching approach. When hiring your child, spell out the steps it will take to complete the task satisfactorily before the work begins. Be specific about what your expectations are. What is the time frame? Is there a bonus for going above and beyond? 
Use the worksheet on the last page of this publication to get your child thinking about earning and saving money.

\section{Spending}

Working together with your children, set guidelines for how they will use their money. For example, will your children have full or limited control over their money? Will a portion be set aside for saving or charity? When children know they will be using portions of their own money for purchases, they become motivated to examine each money decision. A money decision may be as simple as deciding to forego snacks at the movie theatre in lieu of setting aside more spending money for vacation. Making these decisions teaches children how to prioritize and set goals.

Discuss the difference between needs and wants. Give examples of each and ask your children to think of more specific examples. Will their money be used exclusively for their wants? Will they share a portion of the expenses for their needs, such as clothing or school supplies or even saving for college? Children mature in their ability to spend, save, share, and borrow as they use money for each of these purposes.

Start money discussions with your children as early as you can. Small missteps are easier to fix. If your children have to wait longer to make a purchase because they spent more at the fair than they planned to, they will learn a lesson.

The next time they will remember the consequences of not sticking to their plan.

\section{Family Financial Success}

When you work together as a team, the whole family will share a sense of satisfaction with each success, big or small. The toy is a little more special. The day at the amusement park has more meaning.

Educating yourself about how to manage family finances will boost your financial success. Teaching your children how to be good stewards of their money will enhance the family's financial success. Money-wise children are more likely to become money-wise adults.

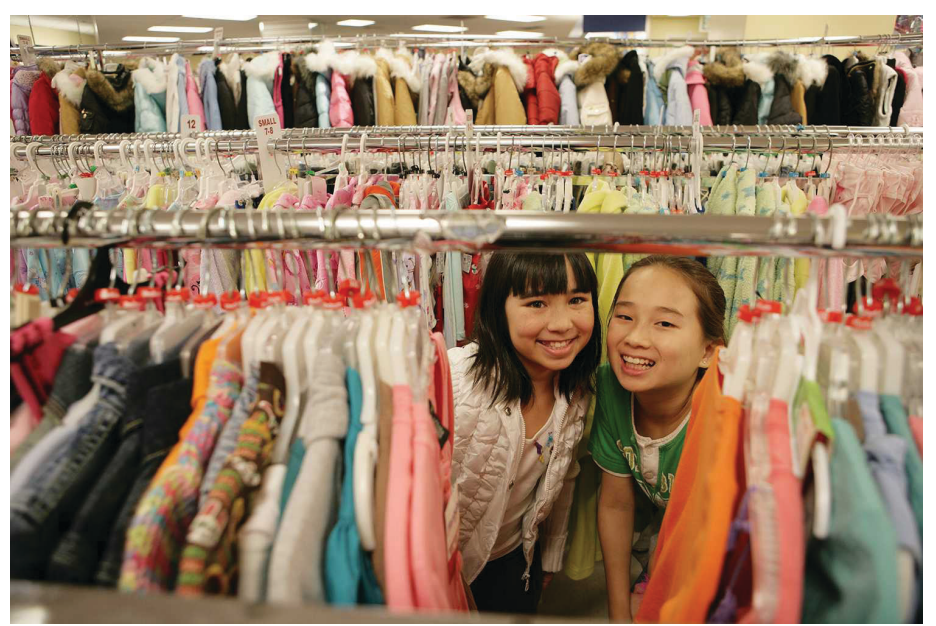

Figure 5. Help your children develop guidelines for their spending, and let them make some of their own financial decisions so they learn about the consequences of their spending. Credits: Eyecandy Images

\section{References}

Danes, S., and T. Dunrud. 2008. Children and Money Series: Teaching Children Money Habits for Life. Minneapolis: University of Minnesota Extension. http://www.extension. umn.edu/distribution/youthdevelopment/DA6116.html.

Hohler, D. 2012. "Teaching Your Children about Saving." America Saves. Accessed February 2013.

http://www.americasaves.org/ september-2012/461-teaching-your-children-about-saving.

Lino, M. 2012. Expenditures on Children by Families, 2011. U.S. Department of Agriculture, Center for Nutrition Policy and Promotion. Miscellaneous Publication No. 1528-2011. http://www.cnpp.usda.gov/Publications/CRC/crc2011.pdf.

Table 1. Overall Annual Estimated Costs (Household Type $=$ One Parent and Income $=$ Less Than $\$ 59,410$ ).

\begin{tabular}{|c|c|c|c|c|c|c|c|c|}
\hline & Housing & Food & Transportation & Clothing & Health Care & $\begin{array}{l}\text { Child Care and } \\
\text { Education }\end{array}$ & Other & Total \\
\hline $\begin{array}{l}\text { National } \\
\text { Costs: }\end{array}$ & $\$ 5,595$ & $\$ 2,758$ & $\$ 1,340$ & $\$ 808$ & $\$ 1,024$ & $\$ 2,758$ & $\$ 1,005$ & $\$ 15,287$ \\
\hline
\end{tabular}




\section{Saving Worksheet}

Name:

What would you like to have?

How much does it cost?

How much money will you need to save each month?

How much money will you need to save each week?

How long will it take you to save for it?

List ways you can earn money. Next to each task, suggest what you believe to be a fair wage. Be reasonable. Even though you suggest an amount, remember that the person who pays you decides how much he or she is willing to pay.

What can I do to earn money?

1.

2.

3.

4.

Are you willing to do the task when you are asked to do it?
What is a fair wage?

$\$$

$\$$

$\$$

$\$$

Are you willing to do the task without being told? 